\title{
Features of clinical course of psoriasis in children depending on haplotypes of the VDR gene and vitamin D level
}

Objective. To compare epidemiological and clinical features of psoriasis in children depending on the studied haplotypes of the VDR gene and vitamin D level. Materials and methods. We examined 56 children with psoriasis, 23 boys and 33 girls aged 4-17, the mean age - 12.30 0.45 years. Psoriasis was determined based on clinical findings and generally accepted diagnostic criteria. The severity and extent of body surface involvement were assessed on PASI, PGA, BSA indices. The buccal epithelium, taken from children, served as the material for genotyping. Polymorphic variants of the VDR gene were detected using the polymerase chain reaction technique and the following restriction fragment length polymorphism analysis. The values were calculated using the STATISTICA software package. Results. Five haplotypes of the VDR gene: TTCC, TTAC, TCAA, TCAC, CCAA were detected in children with psoriasis on the back of the study. Boys outnumbered in TTCC group, while girls in others. The age of disease onset in CCAA group was the youngest

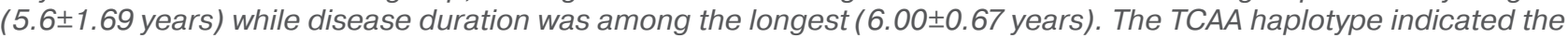
shortest duration of psoriatic exacerbation (4.2 \pm 1.11 weeks), which gradually decreases over the years, and the considerable correlation $(r=-0.56)$ with disease duration takes place. The lowest PGA index was in case of the TCAC hap-

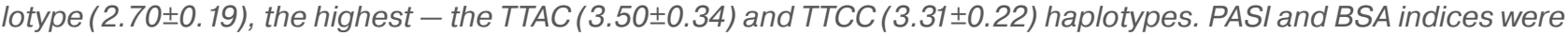
the highest in the presence of the CCAA haplotype. Average serum values of vitamin D in children with psoriasis were

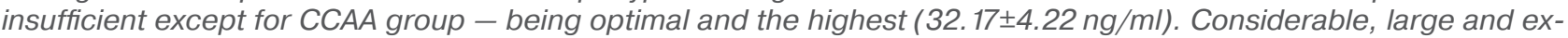
tremely large correlations between vitamin D serum levels in children with psoriasis and disease duration in the presence of TTCC, TTAC and TCAA haplotypes, between disease intensity and extent of body surface involvement in case of CCAA, TCAA and TCAC haplotypes were detected. Conclusions. Genotyping recognized 5 haplotypes - TTCC, TTAC, TCAA, TCAC, CCAA - that predetermine epidemiological and clinical features of psoriasis. It was concluded that in children with the TCAA haplotype, a younger age at the time of disease onset results in more durable exacerbation with age. In case of CCAA and TTAC haplotypes conversely, psoriatic exacerbation is shorter with age. A decrease in the level of serum vitamin D in children having TTCC, TTAC and TCAA haplotypes leads to an increase of exacerbation duration, while in the presence of TCAA, TCAC, CCAA haplotypes - an increase in the severity of psoriasis.

Key words: psoriasis, children with psoriasis, haplotypes of the VDR gene, vitamin D serum level, PASI, PGA, BSA indices of severity.

\section{Introduction}

The role of vitamin $\mathrm{D}$, as the main regulator of skin physiology, is overcomplicated, sequential and strictly controlled (Soleymani T. et al., 2015). Vitamin D precursor, or 7-dehydrocholesterol, accumulates in the membranes of keratinocytes in the basal and spinous layers of the epidermis. The ring of 7-dehydrocholesterol is destroyed to turn into vitamin D precursor, or cholecalciferol, after being exposed to UV radiation (with the wavelength ranging between 290 and $315 \mathrm{~nm}$ ) using photochemical reaction, and then into 1,25-dihydroxyvitamin $D_{3}$ $\left(1,25(\mathrm{OH}) 2 \mathrm{D}_{3}\right)$ or calcitriol - active form of vitamin D (Bikle D.D., 2012). A biologically active form of vitamin $D$ and receptors related regulate differentiation and proliferation of keratinocytes, skin immunity and apoptosis, which are supposed to be potential mechanisms of psoriasis pathogenesis (Milde P. et al., 1991).

It is known that the gene that encodes vitamin $\mathrm{D}$ receptors (VDR) carries a number of polymorphisms. The polymorphic start codon at the 5 ' end of the gene is recognized by the Fokl restriction enzyme. As a part of the gene's 3' end, 3 polymorphisms exist that generate Bsml, Apal and Taql restriction sites (Habuchi T. et al., 2000). Molecular clinical trials provided evidences of certain VDR-related polymorphisms to be potentially associated with bone mineral density, hyperparathyroidism, osteomalacia, insulin-dependent (type I) diabetes mellitus, osteoarthritis and some malignancies such as breast and prostate cancer (Chang T.J. et al., 2000; Habuchi T. etal., 2000; Hutchinson P.E. etal., 2000; BrethetonWatt D. et al., 2001). Genetic polymorphism of the VDR gene can affect $1,25(\mathrm{OH}) 2 \mathrm{D}_{3}$-mediated normal response of keratinocytes.

However, cultivated fibroblasts and keratinocytes in some patients with psoriasis were reported to have partial resistance to antiproliferative activity mediated by 1,25 -dihydroxyvitamin $D_{3}\left[1,25(\mathrm{OH}) 2 \mathrm{D}_{3}\right]$ (MacLaughlin J.A. et al., 1985; Smith E.L. et al., 1988). Although the effectiveness of $1,25(\mathrm{OH}) 2 \mathrm{D}_{3}$ and analogues was tested and turned out to be satisfying for psoriasis treatment (Kragballe K. et al., 1991), clinical response to treatment with $1,25(\mathrm{OH}) 2 \mathrm{D}_{3}$ is not obvious in patients with psoriasis (Mee J.B., Coek M.J., 1998). Testing the antiproliferative effect of calcitriol by experiments was indicative of $25 \%$ of patients with psoriasis having dermal fibroblasts that were partially resistant to calcitriol (MacLaughlin J.A. et al., 1985).

In addition, there is the evidence that polymorphism of vitamin $D$ receptors (VDR) triggers susceptibility to psoriasis. Meta-analysis (Lee Y.H., 2012) revealed the correlation between VDR Apal A allele and psoriasis in Turkish studies (odds ratio $(\mathrm{OR})=0.684$, 95\% confidence interval $(\mathrm{Cl})=0.475-0.985, \mathrm{p}=0.041)$, association between the Bsml $B$ allele and psoriasis in Asians ( $\mathrm{OR}=0.636,95 \% \mathrm{Cl}=0.411-0.984$, $\mathrm{p}=0.041$ ) and indicated the considerable association between FokI FF \& ff genotypes and psoriasis in a plenty of studies, in Turkish in particular $(\mathrm{OR}=2.028,95 \% \mathrm{Cl}=1.194-3.446, \mathrm{p}=0.009$; OR=3.558, 95\% $\mathrm{Cl}=1.660-8.009, \mathrm{p}=0.002$ ).

Objective - to compare epidemiological and clinical features of psoriasis in children depending on genotype combinations by already known Taql and Apal loci of the VDR gene and vitamin D level.

\section{Materials and methods}

Our study involved 56 children with psoriasis, 23 boys and 33 girls, aged $4-17$ (the mean age $-12.30 \pm 0.45$ years), who underwent treatment in Kyiv Municipal Dermatology - STI Clinic, from 2019 till the early part of 2020. Psoriasis was determined based on clinical findings and generally accepted diagnostic criteria. In 19 (33.93\%) children of 56 , psoriasis was recognized for the first time. Disease onset averaged out at $9.13 \pm 0.56$ years. Disease duration ranged from several months to 10 years, $3.13 \pm 0.49$ years on average. The duration of the last exacerba- 
tion in certain children coincided with disease onset and ranged from 2 weeks to 2 years, $12.21 \pm 2.81$ weeks on average. The greatest number of exacerbations developed in January (12), November (11), December (9) and October (7), the smallest - in February and July (1), June (3), August (4). While since March till May patients were not reporting disease exacerbations. It proves that psoriasis exacerbation is more common to develop in autumn - winter months $\left(x^{2}=10.991, p=0.01\right)$. The patient survey showed that only 24 children or their parents were able to indicate the cause of the disease. $18(32.14 \%)$ children associate psoriasis development with stresses and 6 children with the infectious disease (tonsillitis, severe respiratory tract infections). Heredity was indicated as the trigger for the disease to develop in 24 families, where 12 children have relatives of the first generation with psoriasis: 6 children have mothers with psoriasis and 6 - fathers with psoriasis. In 4 children both relatives of the 1 st and 2 nd generation have psoriasis, 6 - have relatives with psoriasis in a family (aunt, uncle, sister).

Types by presentation of the disease mostly involved plaque psoriasis - $39(70,91 \%)$, guttate psoriasis was recognized in 8 (14.29\%) children, inverse psoriasis - in $4(7.14 \%)$ children, scalp psoriasis - in $3(5.36 \%)$ children and palmoplantar type - in $1(1.82 \%)$ children. These types of psoriasis predetermined widespread psoriasis in $46(82.14 \%)$ children and localized in $10(17.86 \%)$ children.

The severity and extent of body surface involvement were assessed on PASI, I/PGA, BSA indices. According to the classification by the U.S. National Psoriasis Foundation the severity of psoriasis in children is assessed on the BSA (Body Surface Area) index - total body surface area affected by the disease process; $1 \%$ of the body surface area is matching with the palm surface area of a patient: mild psoriasis is diagnosed when the $B S A<3$, moderate $3<B S A<10$, severe - the BSA $>10$.

The PASI (Psoriasis Area and Severity Index) is an index for the extent of body surface involvement and severity of psoriasis, reflects the affected body surface area, taking into account the intensity of signs such as erythema, exfoliation and infiltration, the score obtained ranges from 0 to 72 points. The IGA/PGA (Investigator/Physician's Global Assessment Scale) index or PGA is the index of the severity of psoriasis that reflects disease intensity (Table 1).

Table 1. IGA/PGA

\begin{tabular}{lll}
\hline Score & Definition & \multicolumn{1}{c}{ Description of psoriasis } \\
\hline 0 & Clear & No symptoms of psoriasis \\
& & Post-inflammatory discolouration may be present \\
1 & Almost clear & Only minimal plaque elevation, scaling and erythema \\
2 & Mild & Slight plaque elevation, scaling and erythema \\
3 & Moderate & Moderate plaque elevation, scaling and erythema \\
4 & Severe & Very marked plaque elevation, scaling and erythema \\
\hline
\end{tabular}

The assessment of psoriasis severity in children showed that in the majority of children 40 -point (71.43\%) BSA was higher than 10 points and provided the average BSA of $25.21 \pm 2.38$, that indicates the severe course of psoriasis in children according to the area affected.

When estimating the PGA index the average index number was calculated, which equaled $3.05 \pm 0.12$, that gives an opportunity to assess the overall intensity of psoriasis pathogenesis in children as moderate. An in-depth analysis revealed $39.29 \%(n=22)$ of children to have the PGA index being equal to $4-$ severe psoriasis; moderate developed in $26.79 \%$ ( $n=15)$ of children, PGA equals 3; $17(30.36 \%)$ children have the intensity of 2 points and 2 children with $P G A=1$.

The calculated PASI index averaged out at $10.5 \pm 1.29$. The greatest number of children (33 (58.93\%)) had the PASI being up to $10 ; 14$ $(25.0 \%)$ children with the extent of body surface involvement and severity of psoriasis within the range 10-20; 7 (12.5\%) children with the PASI ranging from 20 to 30 and 2 children suffered from psoriasis that was estimated on the PASI index at more than 30 .

The correlation analysis involving a children's age, disease duration, duration of the last exacerbation and indices characterizing a disease process was made and revealed interactions between the intensity of skin lesions (erythema, exfoliation and infiltration) and a children's age. A large positive correlation $(r=0.53)$ takes place that indicates the increase of the intensity of a disease process with age.

We tested vitamin D serum levels, namely $25(\mathrm{OH}) \mathrm{D}$, in children with psoriasis. The analysis was performed in the accredited laboratory. Vitamin D serum levels at $30-60 \mathrm{ng} / \mathrm{ml}$ were considered as optimal, $20-30 \mathrm{ng} / \mathrm{ml}$ - insufficient, less than $20 \mathrm{ng} / \mathrm{ml}$ - deficiency. The study revealed that the average serum level of vitamin $D$ in children with pso- riasis averaged out at $24.81 \pm 0.45 \mathrm{ng} / \mathrm{ml}$, being considered as deficiency, although the optimal serum level of vitamin $D$ is observed in 14 $(25 \%)$ children. Within the deficiency range the level of serum vitamin D was reported in 18 (32.14\%), as insufficient - in 24 (42.86) children.

At the state agency «Reference Center for Molecular Diagnostics of the Ministry of Health of Ukraine", located in Kyiv, we genotyped children with psoriasis in order to determine Apal (A/C) and Taql (T/C) polymorphic variants of the VDR gene. The buccal epithelium, taken from children using sterile brushes, packaged in sterile Eppendorf tubes served as the material for genotyping. The material was stored at $+4^{\circ} \mathrm{C}$. Specimens were transported to the lab by maintaining the cold chain environment.

DNA from buccal cells was isolated using the Quick-DNA ${ }^{\text {TM }}$ Miniprep Plus Kit (Zymo Research, USA) by sticking to the protocol - Buccal Cells and Swabs.

In order to determine Apal and Taql polymorphic variants of the VDR gene modified protocols were applied, implicating the use of oligonucleotide primers in polymerase chain reaction (PCR) technique and the following restriction fragment length polymorphism (RFLP). The target region of the gene was amplified using specific primers (Metabion, Germany), listed in Table 2.

\section{Table 2. Oligonucleotide primers}

\begin{tabular}{llc}
\hline $\begin{array}{c}\text { Gene (polymorphic } \\
\text { variant) }\end{array}$ & \multicolumn{1}{c}{ Primer sequences (5'-3') } & $\begin{array}{c}\text { Length of DNA } \\
\text { regions to be } \\
\text { amplified }\end{array}$ \\
\hline VDR (Apal, & CAGAGCATGGACAGGGAGCAA & $501 \mathrm{bp}$ \\
rs7975232) & CACTTCGAGCACAAGGGGCGTTAGC & \\
VDR (Taql, rs731236) & $\begin{array}{l}\text { CAGAGCATGGACAGGGAGCAA } \\
\text { GCAACTCCTCATGGCTGAGGTCTC }\end{array}$ & $745 \mathrm{bp}$ \\
\hline
\end{tabular}

Amplification was performed by means of the commercial kit referred to as DreamTaq Green PCR Master Mix (2X) (Thermo Scientific, USA). The FlexCycler amplifier (Analytik Jena, Germany) was applied to enable the appropriate thermal mode of PCR.

The amplified product (amplicons) was exposed to hydrolysis by Apal $(10 \mathrm{U} / \mu \mathrm{l})$ and Taql $(10 \mathrm{U} / \mu \mathrm{l})$ restriction endonucleases (Thermo Scientific, USA). A restriction digest was performed in compliance with the manufacturer's guide in a dry block heater for 16 hours at $37^{\circ} \mathrm{C}$ when studying the VDR Apal polymorphism and $65^{\circ} \mathrm{C}$ - the VDR Taql polymorphism. The reaction was terminating by raising the temperature to $65^{\circ} \mathrm{C}$ for 20 minutes when studying the VDR Apal polymorphic variant. The Taql enzyme (the VDR Taql polymorphic variant) did not require the thermal inactivation according to the manufacturer's guide. The state of restriction fragments of the VDR (Apal and Taql) gene was analyzed in a $2 \%$ agarose gel (CSL-AG500 agarose, Cleaver Scientific Ltd, UK) with ethidium bromide acting as a dye. In order to assess the size of fragments a molecular-weight size marker - GeneRuler 100 bp DNA Ladder (Thermo Scientific, USA) was injected. Imaging was performed by utilizing a gel documentation system Micro DOC System with UV Transilluminator Clear View (Cleaver Scientific Ltd, UK). Fragments with the following molecular weight (Table 3) were separated from amplicons due to their hydrolysis.

Table 3. Fragments of VDR polymorphic variants

\begin{tabular}{|c|c|c|c|}
\hline Gene & $\begin{array}{c}\text { Polymorphic } \\
\text { variant }\end{array}$ & $\begin{array}{l}\text { Restriction } \\
\text { endonuclease }\end{array}$ & Size of restriction fragments \\
\hline VDR & Apal, rs7975232 & 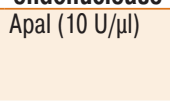 & $\begin{array}{l}\text { AA genotype: } 501 \text { bp } \\
\text { AC genotype: } 501,288 \text { and } 213 \text { bp } \\
\text { CC genotype: } 288 \text { and } 213 \text { bp }\end{array}$ \\
\hline VDR & Taql, rs731236 & 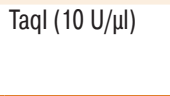 & $\begin{array}{l}\text { TT genotype: } 496 \text { and } 249 \mathrm{bp} \\
\text { TC genotype: } 496,295,249 \text { and } 201 \text { bp } \\
\text { CC genotype: } 295,249 \text { and } 201 \text { bp }\end{array}$ \\
\hline
\end{tabular}

Electropherograms that indicate the gel diffusion of restriction fragments deriving from the VDR Apal and Taql polymorphic variants are illustrated in Figures 1 and 2.

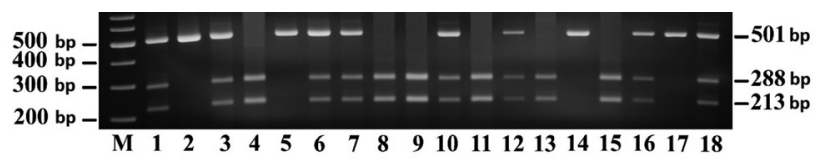

Figure 1. Electropherogram that indicates the gel diffusion of restriction fragments deriving from the VDR Apal and Taql polymorphic variants, where samples $4,8,9,11,13,15$ - CC genotype, samples $1,3,6,7,10,12,16,18$ - AC genotype, samples 2, 5, 14, 17 - AA genotype, $\mathrm{M}$ - a molecular-weight size marker, 100 bp 
Table 4. Epidemiological characteristics of groups by haplotypes of the VDR gene

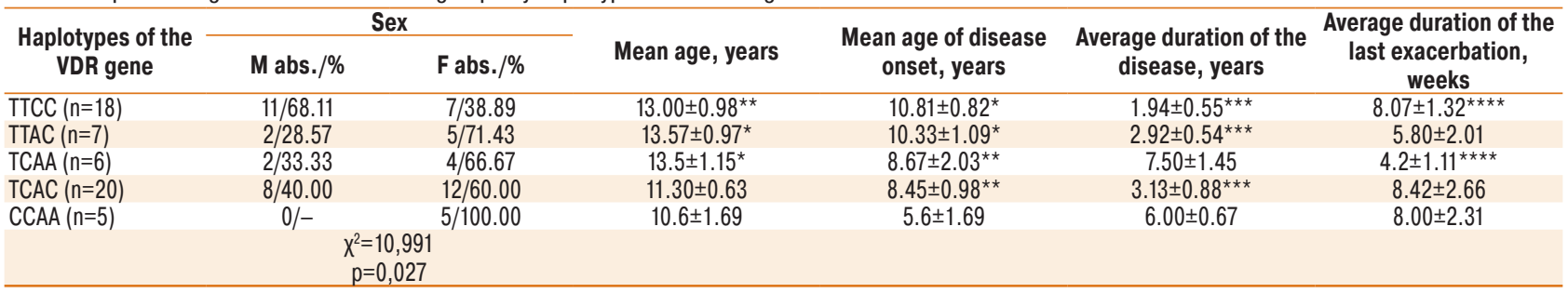

${ }^{*}$ Significant differences at $p \leqslant 0.05$ in case of the CCAA haplotype; ${ }^{* *}$ significant differences at $p \leqslant 0.1$ in case of the CCAA haplotype; ${ }^{* * *}$ significant differences at $p \leqslant 0.05$ in case of the TCAA haplotype; ${ }^{* * * *}$ significant differences at $p \leqslant 0.05$ between values.

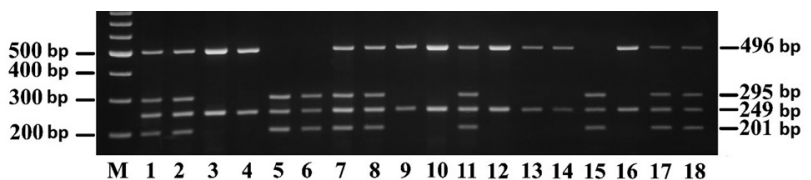

Figure 2. Electropherogram that indicates the gel diffusion of restriction fragments deriving from the VDR Apal and Taql polymorphic variants, where samples 5, 6, 15 - CC genotype, samples 1, 2, 7, 8, 11, 17, 18 - TC genotype, samples $3,4,9,10,12-14,16$ - TT genotype, $\mathrm{M}$ - a molecular-weight size marker, $100 \mathrm{bp}$

The values were calculated using the STATISTICA software package. The probability $p=0.05$ (95\% confidence level) served as the level of statistical significance. Testing of statistical hypotheses for the association of alleles recognized and disease-associated genotypes, and the assessment of lane straightness were made by sticking to the $\chi^{2}$ criterion characterized by significance level, not more than 0.05 , with subsequent interpretation of statistical criteria obtained in compliance with the guide by Rea \& Parker, and the Fisher transformation

\section{Results and discussion}

As a result of the study we compared the frequency of genotype combinations by already known Taql (T/A) and Apal $(A / C)$ loci of the VDR gene and detected 5 haplotypes in children with psoriasis. Depending on haplotypes detected children were split up into groups: TTCC haplotype -18 , TTAC -7 , TCAA -6 , TCAC -20 , CCAA 5 children.

When comparing clinical features of the groups formed according to haplotypes of the VDR gene, we found that only in TTCC group boys outnumbered, while in other groups girls prevailed in number, and, moreover, this difference is statistically significant, whereas in CCAA group boys were absent at all (Table 4). Certain studies indicate the prevalence of psoriasis in men (Bakulev A.L. et al., 2018). The study by J.M. Gelfand et al. (2005), in contrast, suggested that the prevalence of psoriasis under the age of 20 was growing faster in women than in men. The multicenter cross-sectional study among children with psoriasis in the US revealed the ratio between men and women of 1.48 (Mercy K. et al., 2013).

The youngest age of children with psoriasis was reported in CCAA group (10.6 \pm 1.69 years), which apparently differed from the mean age in TTCC (13.00 \pm 0.98 years) and TTAA ( $13.57 \pm 0.97$ years) groups. Accordingly, the age of disease onset in CCAA group was the youngest (5.6 \pm 1.69 years) comparing to other groups at the level of a statistically significant difference to the groups representing the TTCC haplotype (10.81 \pm 0.82 years), TTAC haplotype (10.33 \pm 1.09 years), and at the level of a central tendency, concurrent with the groups representing the TCAA haplotype ( $8.67 \pm 2.03$ years) and TCAC ( $8.45 \pm 0.98$ years). To be specific, we can trace that in the presence of CCAA the age of disease onset is younger than a central tendency for psoriasis onset, which in lots of studies coincides with 8-11 years of age (Seyhan M. et al., 2006; Tollefson M.M. et al., 2010; Kwon H.H. et al., 2012; Shah K.N., 2013)

When assessing the duration of psoriasis in children it was found that the most durable disease was observed in children with CCAA (6.00 0.67 years) and TCAA haplotypes $(7.50 \pm 1.45$ years) that, at the level of statistical significance, differed from groups with TTCC haplotypes ( $1.94 \pm 0.55$ years), where duration was the smallest, and TTAC (2.92 \pm 0.54 years) with TCAC (3.13 \pm 0.88 years). But, as opposed to the longest disease duration, the shortest duration of exacerbation was observed in case of the TCAA haplotype
(4.2 \pm 1.11 weeks). In case of the shortest disease duration, related to the TTCC haplotype, the duration of exacerbation is quite long (8.07 \pm 1.32 weeks), which made a possible difference between the groups.

The correlation analysis was indicative of positive and negative correlations, large and extremely large ones. It is not unreasonable to assume that the younger the child at the time of disease onset, the longer the disease duration is. It proves the existence of a large negative correlation in groups of children with TCAA $(r=-0,85)$ and TCAC ( $r=-0.72)$ haplotypes, and medium negative correlation in groups with TTAC $(r=-0,39)$ and CCAA $(r=-0.44)$ haplotypes. However, for the group of children with the TTCC haplotype no correlations between the age of disease onset and disease duration were detected (Table 5).

Table 5. Correlations depending on the haplotype of the VDR gene

\begin{tabular}{lccc}
\hline \multicolumn{1}{c}{ Parameter } & $\begin{array}{c}\text { Haplotypes } \\
\text { of the VDR gene }\end{array}$ & $\begin{array}{c}\text { Disease } \\
\text { duration, years }\end{array}$ & $\begin{array}{c}\text { Duration } \\
\text { of the last } \\
\text { exacerbation, } \\
\text { weeks }\end{array}$ \\
\hline Age of a child at the & TTCC $(n=18)$ & 0.049 & -0.36 \\
time of disease onset, & TTAC $(n=7)$ & -0.39 & 0.54 \\
years & TCAA (n=6) & -0.85 & -0.85 \\
& TCAC $(n=20)$ & -0.72 & -0.23 \\
Disease duration, & CCAA $(n=5)$ & -0.44 & 0.74 \\
years & TTCC $(n=18)$ & & 0.39 \\
& TTAC $(n=7)$ & & 0.15 \\
& TCAA $(n=6)$ & & -0.56 \\
& TCAC $(n=20)$ & & 0.28 \\
\hline
\end{tabular}

\section{- extremely large correlation}

- large correlation

- relatively large correlation

- medium correlation

- small correlation

no correlation

The analysis of correlations between the children age at the time of disease onset and the duration of the exacerbation revealed the existence of multidirectional correlations. In children from the group with TCAA, TTCC and TCAC haplotypes the age increase leads to a reduction in the duration of exacerbation, large negative correlation in TCAA group $(r=-0.85)$, medium negative $(r=-0,36)$ in TTCC group, small negative $(r=-0.23)$ in TCAC group. While in children with CCAA and TTAC haplotypes the duration of psoriasis exacerbations increases with age, the correlation is positive large and relatively large, $r=0.74$ and $r=0.54$, respectively. Negative correlations between the duration of the disease and the last exacerbation, when such a correlation for children of CCAA group is extremely large negative $(r=-0.94)$ and TCAA group - medium negative $(r=-0.56)$, lend credence to the statement as well. It means that in these groups of children the longer the disease duration, the shorter the exacerbation period is.

No evidence of the VDR haplotype having an impact on the presence of certain psoriasis types in children and the extent of body surface involvement.

In each group of children plaque psoriasis prevailed, from $60.00 \%$ in CCAA group to $83.33 \%$ in TTCC group. According to the types of psoriasis, the number of widespread types is also set, the greatest number of which is observed in TTCC group of children (88.89\%).

To provide insights into clinical characteristics of certain groups we assessed the severity and extent of body surface involvement on PASI, PGA, BSA indices (Table 6). 
Table 6. Indices of the severity and extent of body surface involvement in groups of children with psoriasis depending on haplotypes of the VDR gene

\begin{tabular}{cccccccc}
$\begin{array}{c}\text { Haplotypes } \\
\text { of the VDR }\end{array}$ & PASI & PGA & BSA & \multicolumn{3}{c}{$\begin{array}{c}\text { Correlation } \\
\text { coefficients }\end{array}$} \\
\cline { 3 - 7 } gene & & & & $\begin{array}{c}\text { PASI } \\
\text { \& PGA \& BSA }\end{array}$ & BSA \& \\
\hline TTCC $(n=18)$ & $12.25 \pm 2.21^{*}$ & $3.31 \pm 0.22^{* *}$ & $27.78 \pm 4.44^{*}$ & 0.53 & 0.90 & 0.40 \\
TTAC $(n=7)$ & $12.83 \pm 3.45^{*}$ & $3.50 \pm 0.34$ & $26.93 \pm 6.31^{*}$ & 0.67 & 0.82 & 0.65 \\
TCAA $(n=6)$ & $9.28 \pm 4.68^{*}$ & $3.00 \pm 0.36$ & $19.15 \pm 5.57^{*}$ & 0.83 & 0.99 & 0.76 \\
TCAC $(n=20)$ & $8.08 \pm 1.06^{*}$ & $2.70 \pm 0.19^{* *}$ & $21.76 \pm 2.34^{*}$ & 0.55 & 0.83 & 0.33 \\
CCAA $(n=5)$ & $31.63 \pm 5.27$ & $3.40 \pm 0.30$ & $48.33 \pm 6.63$ & 0.84 & 0.92 & 0.77
\end{tabular}

${ }^{*}$ Significant differences at $p \leqslant 0.05$ in case of the CCAA haplotype;** significant differences at $p \leqslant 0.05$, between values.

\section{- extremely large correlation \\ - large correlation \\ - relatively large correlation \\ - medium correlation}

The findings showed that the PGA, or the severity index, indicating the intensity of the disease process, is almost equal for all haplotype groups. But it was reported as the smallest in TCAC group (2.70 \pm 0.19$)$, characterizing the severity as moderate; the biggest in children from

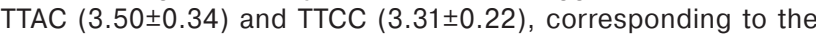
moderate-severe course, and providing a statistically significant difference between values among groups. Psoriasis Area and Severity Index (PASI) that indicates the area of body surface involvement, taking into account the intensity of signs such as erythema, exfoliation and infiltration, was the smallest in TCAC group (8.08 \pm 1.06$)$ as well, and significantly bigger than other values in children from CCAA group (31.63 \pm 5.27$)$ and demonstrated a statistically significant difference to PASI indices of other groups. By default the BSA, or Body Surface Area, affected by a disease, characterizes the course of psoriasis in case of all haplotypes as severe. The highest index was observed in CCAA group (48.33 \pm 6.63$)$, which is probably different from the BSA in other groups. The correlation analysis of indices revealed that in all groups the largest correlation takes place between PASI and BSA indices, there are positive large and extremely large correlations, correlation coefficients range from 0.82 to 0.99 . It enables the use of both BSA and PASI indices in order to assess the severity of psoriasis in children over 4 years of age.

Multiple tests of the average level of serum vitamin D in children with psoriasis gave us the overall view regarding the deficiency and insufficient level of serum vitamin D $(25(\mathrm{OH}) \mathrm{D})$ almost in $75 \%$ of children. A correlation analysis did not provide any meaningful measurements. Thus we also carried out the analysis of vitamin D $(25(\mathrm{OH}) \mathrm{D})$ serum level in children with psoriasis depending on haplotypes of the VDR gene (Table 7).

Table 7. The average level of serum vitamin $D$ in children with psoriasis depend ing on haplotypes of the VDR gene and correlations involving severity indices

\begin{tabular}{lccccc}
\hline $\begin{array}{c}\text { Haplotypes of } \\
\text { the VDR gene }\end{array}$ & $\begin{array}{c}\text { Average } \\
\text { vitamin D level } \\
\text { (ng/ml) }\end{array}$ & $\begin{array}{c}\text { Duration of } \\
\text { exacerbation, } \\
\text { weeks }\end{array}$ & PASI & PGA & BSA \\
\hline TTCC $(n=18)$ & $25.93 \pm 3.19$ & -0.50 & 0.46 & 0.28 & 0.01 \\
TTAC $(n=7)$ & $23.04 \pm 3.60^{*}$ & -0.60 & 0.45 & -0.26 & 0.19 \\
TCAA $(n=6)$ & $26.64 \pm 3.09$ & -0.65 & -0.39 & -0.78 & -0.23 \\
TCAC $(n=20)$ & $22.36 \pm 2.37^{*}$ & 0.05 & -0.34 & -0.7 & -0.37 \\
CCAA $(n=5)$ & $32.17 \pm 4.22$ & 0.49 & -0.99 & -0.86 & -0.71 \\
\hline
\end{tabular}

* Significant differences at $p \leqslant 0.05$ in case of the CCAA haplotype.

- extremely large correlation
- large correlation
- medium lium correlation
- small correlation
- no correlation

The average level of serum vitamin D (25(OH)D) was insufficient in 4 groups of children with psoriasis, divided according to haplotypes of the VDR gene, only in CCAA group the level of serum vitamin D in children with psoriasis appeared to be optimal and was the highest $(32.17 \pm 4.22 \mathrm{ng} / \mathrm{ml})$. The lowest levels of serum vitamin $D$ in children with psoriasis were reported in case of TCAC $(22.36 \pm 2.37 \mathrm{ng} / \mathrm{ml})$ and TTAC $(23.04 \pm 3.60 \mathrm{ng} / \mathrm{ml})$ haplotypes that are apparently lower than vitamin $D$ serum levels in children with the CCAA haplotype.

A large number of literary works are devoted to the role of vitamin $D$ in psoriasis pathogenesis, nevertheless we didn't find any studies of how vitamin D serum levels interrelate with other clinical characteristics of the disease process. When analyzing interrelations between vitamin $D$ serum levels in children and psoriasis highly controversial results were obtained. The duration of the disease in groups representing TTCC, TTAC and TCAA haplotypes was associated with the content of vitamin $D$ in blood serum, the lower the level of serum vitamin $D$ in children, the more durable the disease process is - the correlation is large negative $(r=-0.50, r=-0.60$ and $r=-0.65$, respectively).

However, when studying interrelations between the level of serum vitamin D in children and psoriasis as well as the severity indices (PASI, PGA, BSA), negative large and extremely large correlations ( $r=-0.99$, $r=-0.86, r=-0.71$, respectively) were detected specifically in CCAA group. This indicates the effect of vitamin D serum level in children with psoriasis on manifestations of the disease: a decrease in the level of serum vitamin D leads to an increase in the intensity of manifestations and extent of body surface involvement. Also the level of serum vitamin $D$ has an effect on the intensity of skin manifestations in psoriasis (PGA index), in TCAA and TCAC groups to be exact: there is a large negative correlation between the level of vitamin $D$ and the PGA index ( $r=-0.78$ and $r=-0.70$, respectively).

\section{Conclusions}

While genotyping, supposed to recognize Apal (A/C) and Taql (T/C) polymorphic variants of the VDR gene, 5 haplotypes, or TTCC, TTAC, TCAA, TCAC, arise in children with psoriasis, depending on which epidemiological and clinical features of psoriasis develop.

It was found that in children with psoriasis and the TCAA haplotype a younger age at the time of disease onset predetermines more durable exacerbation with age, $r=-0.85$. In the presence of CCAA and TTAC haplotypes, on the contrary, the younger the age of disease onset, the shorter is the duration of exacerbation period with age, $r=-0.74$ and $r=-0.54$, respectively.

It was found that the average level of serum vitamin D in children with psoriasis and the CCAA haplotype is within the optimum range $(32.17 \pm 4.22 \mathrm{ng} / \mathrm{ml})$, whose difference from vitamin $D$ levels in groups of children holding TTAC and TCAC haplotypes $(23.04 \pm 3.60 \mathrm{ng} / \mathrm{ml}$ and $22.36 \pm 2.37 \mathrm{ng} / \mathrm{ml})$ is of statistical significance, a homozygous dominant genotype $A A$ is likely to be selectively significant for regulating the level of serum vitamin $D$ in children with psoriasis.

The study revealed that a decrease in the level of serum vitamin D in children with psoriasis and TTCC, TTAC and TCAA haplotypes provokes an increase in the duration of the disease, correlation coefficients $r=-0.50, r=-0.60, r=-0.65$, respectively.

The study suggested that the decrease of vitamin $D$ serum level in children with psoriasis and TCAA, TCAC, CCAA increases the intensity of manifestations (erythema, exfoliation, infiltration), correlation coefficients $r=-0.78, r=-0.70, r=-0.86$, respectively. In children with psoriasis with such haplotypes, we can expect good treatment results while using vitamin D in complex therapy.

\section{Reference list}

Bakulev A.L., Fitileva T.V., Novoderezhkina E.A. et al. (2018) Psoriasis: clinical and epidemiological features and therapy issues. Vest. Dermatol. Venerol., 94(3): 67-76. doi.org/10.25208/0042-4609-2018-94-3-67-76.

Bikle D.D. (2012) Protective actions of vitamin D in UVB induced skin cancer. Photochem. Photobiol. Sci., 11(12): 1808-1816. doi.org/10.1039/c2pp25251a.

Bretheton-Watt D., Given-Wilson R., Mansi L. et al. (2001) Vitamin D receptor gene polymorphisms are associated with breast cancer risk in a UK Caucasian population. Br. J. Cancer, 85: 171-75. doi.org/10.1054/bjoc.2001.1864.

Chang T.J., Lei H.H., Yeh J.I. et al. (2000) Vitamin D receptor gene polymorphism influence susceptibility to type 1 diabetes mellitus in the Taiwanese population. Clin. Endocrinol., 52: 569-575. doi.org/10.1046/j.1365-2265.2000.00985.x.

Gelfand J.M., Weinstein R., Porter S.B. et al. (2005) Prevalence and treatment of psoriasis in the United Kingdom: a population-based study. Arch. Dermatol., 141(12): 1537-1541. doi.org/10.1001/archderm.141.12.1537.

Habuchi T., Suzuki T., Sasaki R. et al. (2000) Association of Vitamin D receptor gene polymorphism with prostate cancer and benign prostatic hyperplasia in Japanese population. Cancer Res., 60: 305-308. doi.org/10.1038/sj.pcan.4500349.

Hutchinson P.E., Osborn J.E., Lear J.T. et al. (2000) Vitamin D receptor polymorphism are associated with altered prognosis in patients with maligmamt melanoma. Clin. Cancer Res., 6: 498-504.

Kragballe K., Gjertsen B., DeHoop D. et al. (1991) Double-blind, right/left comparison of calcipotriol and betamethasone valerate in treatment of psoriasis vulgaris. Lancet, 337: 193-196. doi.org/10.1016/0140-6736(91)92157-w. 
Kwon H.H., Na S.J., Jo S.J., Youn J.I. (2012) Epidemiology and clinical features of pediatric psoriasis in tertiary referral psoriasis clinic. J. Dermatol., 39(3): 260-264. doi.org/10.1111/j.1346-8138.2011.01452.x

Lee Y.H., Choi S.J., Ji J.D., Song G.G. (2012) Vitamin D receptor Apal, Taql, Bsml, and Fokl polymorphisms and psoriasis susceptibility: a meta-analysis. Mol. Biol. Rep., 39(6): 6471-6478. doi: 10.1007/s11033-012-1466-6.

MacLaughlin J.A., Gange W., Taylor D. et al. (1985) Cultured psoriatic fibroblasts from involved and uninvolved sites have a partial but not absolute resistance to the proliferation-inhibition activity of 1,25-dihydroxyvitamin D3. Proc. Natl. Acad. Sci. USA, 82: 5409-5412. doi.org/10.1073/pnas.82.16.5409.

Mee J.B., Coek M.J. (1998) Vitamin D receptor polymorphism and calcipotrio response in patients with psoriasis. J. Invest. Dermatol., 110: 301. doi. org/10.1046/j.1523-1747.1998.00128.x.

Mercy K., Kwasny M., Cordoro K.M. et al. (2013) Clinical manifestations of pediatric psoriasis: results of a multicenter study in the United States. Pediatr. Dermatol., 30(4): 424-428. doi.org/10.1111/pde.12072.

Milde P., Hauser U., Simon T. et al. (1991) Expression of 1,25-dihydroxyvitamin D3 receptors in normal and psoriatic skin. J. Invest. Dermatol., 97: 230-239. doi. org/10.1111/1523-1747.ep12480255.

Seyhan M., Coskun B.K., Saglam H. et al. (2006) Psoriasis in childhood and adolescence: evaluation of demographic and clinical features. Pediatr. Int., 48(6): 525-530. doi.org/10.1111/j.1442-200x.2006.02270.x.

Smith E.L., Pincus S.H., Donovan L., Holick M.F. (1988) A novel approach for the evaluation and treatment of psoriasis: oral or topical use of 1,25-dihydroxyvitamin D3 can be a safe and effective therapy for psoriasis. J. Am. Acad. Dermatol., 19: 516-528. doi.org/10.1016/s0190-9622(88)70207-8.

Shah K.N. (2013) Diagnosis and treatment of pediatric psoriasis: current and future. Am. J. Clin. Dermatol., 14(3): 195-213. doi.org/10.1007/s40257-013-0026-8.

Soleymani T., Hung T., Soung J. (2015) The role of vitamin D in psoriasis: a review. Int. J. Dermatol., 54(4): 383-392. doi.org/10.1111/ijd.12790.

Tollefson M.M., Crowson C.S., McEvoy M.T., Kremers H.M. (2010) Incidence of psoriasis in children: a population-based study. J. Am. Acad. Dermatol., 62(6): 979-987. doi.org/10.1016/j.jaad.2009.07.029.

\section{Особливості перебігу псоріазу у дітей залежно від гаплотипів за геном VDR та рівнем вітаміну D}

\section{Е.О. Мурзіна}

Резюме. Мета: провести зіставлення епідеміологічних, клінічних особливостей перебігу псоріазу у дітей залежно від виявлених гаплотипів за геном VDR та рівнем вітаміну D. Об'єкт і методи дослідження. Обстежено 56 дітей із псоріазом, 23 хлопці та 33 ді-

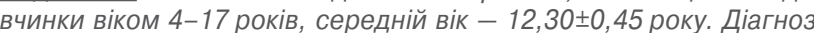
«псоріаз» встановлювали на підставі клінічних даних та загальноприйнятих діагностичних критеріїв. Оцінку тяжкості перебігу та розповсюдженості патологічного процесупроводили за індексами PASI, PGA, BSA. Матеріалом для генотипування слугував букальний епітелій дітей. Визначення поліморфних варіантів за геном VDR проводили із застосуванням методу полімеразної ланцюгово реакції та подальшим аналізом поліморфізму довжин рестрикційних фрагментів. Підрахунок показників здійснювали за допомогою пакета STATISTICA. Результати. У дітей із псоріазом встановили 5 гаплотипів за геном VDR: TTCC, TTAC, TCAA, TCAC, CCAA. У групі ТTCС за кількістю превалювали хлопці, в інших - дівчата. Вік початкузахворювання угрупі ССАА був найменшим $(5,6 \pm 1,69$ року), тривалість захворювання - одна з найдовших $(6,00 \pm 0,67$ року). У разі гаплотипу ТСАА виявлена найменша тривалість загострення псоріазу $(4,2 \pm 1,11$ тиж), яка поступово зменшувалася з роками наявний зворотний значний кореляційний зв'язок із тривалістю захворювання, $r=-0,56$. Найнижчим індекс тяжкості псоріазу за PGA був при гаплотипі TCAC $(2,70 \pm 0,19)$, найвищим - при гаплотипах $\operatorname{TTAC}(3,50 \pm 0,34)$ та TTCC $(3,31 \pm 0,22)$. Індекси PASI та BSA найвищими були при гаплотипі CCAA. Середній рівень вітаміну D у сироватці крові дітей із псоріазом був у межах недостатнього, лише у групі з гаплотипом ССАA - в межах оптимального та був найви-

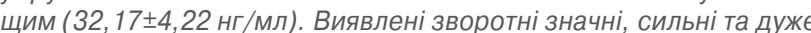
сильні кореляційні зв'язки між рівнем вітаміну D у сироватці крові дітей із псоріазом і тривалістю патологічного процесу при гаплотипах ТTСС, ТТАС та ТСАА, інтенсивністю проявів та розповсюдженістю патологічного процесу при гаплотипах ССАA, TCAA і TCAC. Висновки. У дітей із псоріазом залежно від гаплотипів за геном VDR - TTCC, TTAC, TCAA, TCAC, CCAA - формуються епідеміологічні та клінічні особливості перебігу псоріазу. Встановлено, що у дітей із псоріазом гаплотип ТСАА зумовлює початок захворювання в більш ранньому віці (5-6 років) та збільшення тривалості за гострення патологічного процесу з віком. При гаплотипах ССАA і TTAC, навпаки, загострення псоріазу з віком коротшає. Зниження рівня вітаміну D у сироватці крові дітей із псоріазом з гаплотипами TTCC, TTAC та TCAA призводить до збільшення тривалості загострення захворювання, а з гаплотипами ТСАA, ТСАС, ССАA до збільшення інтенсивності шкірних проявів псоріазу.

Ключові слова: псоріаз, діти з псоріазом, гаплотипи за геном VDR, рівень вітаміну D у сироватці крові, індекси тяжкості псоріазу PASI, $P G A, B S A$.

\section{Особенности течения псориаза у детей в зависимости от гаплотипов гена VDR и уровня витамина D}

\section{Э.А. Мурзина}

Резюме. Цель: провести сопоставление эпидемиологических, клинических особенностей течения псориаза у детей в зависимости от выявленных гаплотипов гена VDR и уровнем витамина D. Объект и методы исследования. Обследовано 56 детей с псориазом, 23 мальчика и 33 девочки в возрасте 4-17 лет, средний воз-

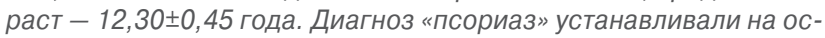
новании клинических данных и общепринятых диагностических критериев. Оценку тяжести и распространенности патологического процесса проводили по индексам PASI, PGA, BSA. Материалом для генотипирования служил буккальный эпителий детей. Определение полиморфных вариантов по гену VDR проводили с применением метода полимеразной цепной реакции и последующим анализом полиморфизма длин рестрикционных фрагментов. Расчет показателей осуществляли с помощью пакета STATISTICA. Результаты. У детей с псориазом выявили 5 гаплотипов гена VDR: TTCC, TTAC, TCAA, TCAC, CСAA. В группе ТTCС по количеству превалировали мальчики, в остальных группах - девочки. Возраст на-

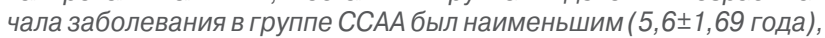
продолжительность заболевания - одна из самых длинных

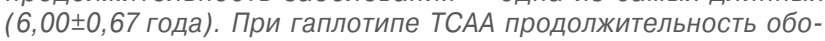
стрения псориаза наиболее короткая (4,2ะ1,11 нед), и постепенно уменьшалась с годами, выявлена обратная значительная корреляционная связь с длительностью заболевания $(r=-0,56)$. Наименьшим индекс тяжести псориаза PGA был при гаплотипе $\operatorname{TCAC}(2,70 \pm 0,19)$, наибольшим - при гаплотипах TTAC $(3,50 \pm 0,34)$

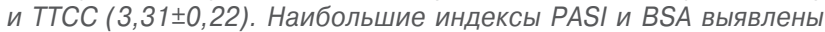
при гаплотипе CCAA. Средний уровень витамина D в сыворотке крови детей с псориазом был в пределах недостаточного, в группе с гаплотипом ССАA - в пределах оптимального и был самым

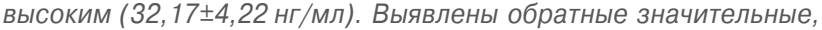
сильные и очень сильные корреляционные связи между уровнем витамина $D$ в сыворотке крови детей с псориазом и продолжительностью патологического процесса при гаплотипах ТTCС, TTAC и ТСАА, интенсивностью проявлений и распространенностью патологического процесса при гаплотипах ССАA, TCAA и TCAC. Выводы. В зависимости от наличия гаплотипа гена VDR - TTCC, TTAC, TCAA, TCAС или ССАА - формируются эпидемиологические и клинические особенности псориаза. Установлено, что у детей с псориазом гаплотип ТСАА обусловливает начало заболевания в раннем возрасте (5-6 лет) и увеличение длительности обострений патологического процесса с возрастом. У детей с гаплотипами ССАА и TTAC, наоборот, обострения псориаза с возрастом укорачиваются. Снижение уровня витамина D в сыворотке крови детей с псориазом с гаплотипами ТTCC, ТTAC и TСАA приводит к увеличению продолжительности обострения заболевания, а с гаплотипами ТСАА, ТСАС, ССАА - усилению интенсивности кожных проявлений псориаза

Ключевые слова: псориаз, дети с псориазом, гаплотипы по гену VDR, уровень витамина D в сыворотке крови, индексы тяжести псориаза PASI, PGA, BSA.

\section{Information about the author:}

Murzina Elvina

04112, Kyiv, Dorohozhytska Str., 9

Shupyk National Medical Academy

of Postgraduate Education,

Department of Dermatovenereology

E-mail: elvina2003@ukr.net 